\title{
Corticolous Myxomycetes in three different habitats in southern Finland
}

\author{
MARJA HÄRKÖNEN
}

\begin{abstract}
HÄRKÖNEN, M. 1977: Corticolous Myxomycetes in three different habitats in southern Finland. - Karstenia 17: 19-32.

Bark from living trees was periodically collected from three localities in southern Finland: from an urban, air-polluted park, a virgin forest and a managed forest, representing similar boreal coniferous forest areas. In moist chambers 19 species of Myxomycetes appeared on the pieces of bark. Eight are new to Finland: Echinostelium minutum de Bary, $E$. cribrarioides Alex., Perichaena chrysosperma (Currey) A. Lister, Stemonitis pallida Wingate, Comatricha elegans (Racid.) G. Lister, Paradiacheopsis fimbriata (G. Lister \& Cran) Hertel, $P$. solitaria (Nann.-Brem.) Nann.-Brem., Physarum pusillum (Berk. \& Curt.) G. Lister. Six species were abundant: Echinostelium minutum de Bary, Arcyria pomiformis (Leers) Rost., A. cinerea (Bull.) Pers., Comatricha nigra (Pers.) Schroet., Enerthenema papillatum (Pers.) Rost. and Paradiacheopsis fimbriata (G. Lister \& Cran) Hertel.

Slime moulds appeared on bark with a wide range of $\mathrm{pH}, 2-9$. Some species, e.g. Comatricha nigra, seemed to prefer an acid substrate, others, e.g. Arcyria cinerea, a less acid one. Among the common species the incubation time needed for fructifications to develop varied from a couple of days to over 40 days. Bark from the urban locality yielded many fructifications but of only six species. Paradiacheopsis fimbriata was very common and formed large colonies in places inhabited by the lichen Bacidia chlorococca (Stenh.) Lett., which is highly resistant to atmospheric pollution. Bark from the virgin forest produced fewer fructifications, but of many more species (16). Bark from the managed forest had few fructifications and few species (5). With the moist chamber culture method no phenological variation can be shown.
\end{abstract}

Marja Harkönen, Department of Botany, University of Helsinki, Unioninkatu 44, SF-00170 Helsinki 17, Finland

I. Materials and methods ............. 19

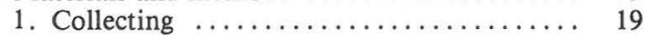

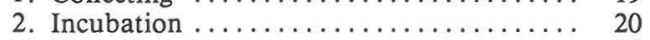

3. Documentation ................. 20

II. List of species .................... 20

III. Ecology ..................... 29

1. Different tree species as habitats for

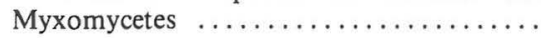

\section{Materials and methods}

\section{Collecting}

Bark from living trees was collected in three localities in the province of Uusimaa:

Helsinki, The Botanical Garden of the University of Helsinki, in the centre of the city (Grid $27^{\circ} \mathrm{E}$ : $6675: 386$ )

Espoo, Luukkaa, a virgin forest, about $25 \mathrm{~km}$ northwest of Helsinki (Grid $27^{\circ} \mathrm{E}:$ 6693:373)

Vantaa, Seutula, a managed forest, $20 \mathrm{~km}$ north of Helsinki (Grid $27^{\circ} \mathrm{E}$ : 6689:388)

2. $\mathrm{pH}$ of the substrate $\ldots \ldots \ldots \ldots \ldots \ldots . \quad 30$

3. The three habitats as producers of

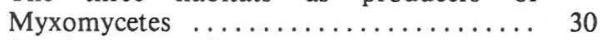

4. Corticolous species ................. 31

5. Seasonal appearance $\ldots \ldots \ldots \ldots \ldots \ldots . \ldots \ldots \ldots$

6. Incubation time $\ldots \ldots \ldots \ldots \ldots \ldots \ldots, 31$

References..................... 32

The Botanical Garden was chosen to represent an airpolluted place. Even in the 1930s the lichens on the trunks were deteriorating or had disappeared (Vaarna 1934), and nowadays almost no corticolous mosses or lichens are to be found there except Bacidia chlorococca (Stenh.) Lett. Luukkaa and Seutula are two similar boreal coniferous forest areas including some rocky places with scanty undergrowth of Juniperus and moist depressions lined with Sphagnum. The main trees are Picea abies, Pinus sylvestris, Betula pendula and $B$. pubescens. Other frequent tree species are Alnus glutinosa (more in Luukkaa) and $A$. incana (more in Seutula), Populus tremula, Salix caprea and Sorbus aucuparia. The difference is that 
Seutula receives normal silvicultural treatment although not recently treated with fertilizers or other chemicals and Luukkaa is left in a natural condition.

From October 1974 to May 1975 I collected tree bark for about 20 moist chambers every other week from the Botanical Garden and from the virgin forest. During May to November 1975 the project was extended to the managed forest, and bark was collected for 25 moist chambers from each of these three places every other week. In the Botanical Garden material was collected from both native and foreign tree species, about half from deciduous trees and half from conifers. From the forests equal amounts bark from corresponding tree species were collected. Each time bark from Betula, Picea and Pinus were included, and other trees sampled were Juniperus, Alnus, Salix caprea and Populus tremula. All bark specimens were taken from a convenient height below about $1.5 \mathrm{~m}$. I was careful not to take living wood within. Every specimen was placed in a separate, clean paper bag. In all, bark was incubated in 1209 moist chambers.

\section{Incubation}

The bark was put in clean Petri dishes (diam. $9 \mathrm{~cm}$ ), lined with filter paper. The bark formed a single layer covering the bottom as entirely as possible. The dishes were then filled with distilled water (adjusted with $\mathrm{KOH}$ to $\mathrm{pH} 7$ ) and the covers put on. After $24 \mathrm{~h}$ the surplus water was poured off and the covers replaced. After another $24 \mathrm{~h}$ the $\mathrm{pH}$ of the moisture in the dishes was measured to the nearest $0.5 \mathrm{pH}$ unit with pH sticks (Merck Universalindicator). The Petri dishes were kept in normal room conditions (cf. v. Stosch 1965) in diffuse daylight (cf. Gray 1938). The dishes were examined daily under a dissecting microscope for 4 weeks. When developing sporangia were found, the $\mathrm{pH}$ was measured once more and the cover left slightly open so that the moist chamber dried slowly. The following day the sporangia were usually mature, and if so the cover was removed. In some cases the plasmodium did not form sporangia, but turned into a sclerotium or died. From June to November 1975 I dried those chambers which had not produced slime mould fructifications and rewetted them 2 weeks later. The $\mathrm{pH}$ was measured once more, and the Petri dishes observed for 3 more weeks.

\section{Documentation}

Representative specimens are deposited at herbarium $\mathrm{H}$. Because many specimens were scanty, I preserved a permanent slide of every one, and some specimens exist only as a permanent slide. At first the specimens were mounted in lactic acid, but this was laborious, and later Hoyer's medium (see Martin \& Alexopoulos 1969) was used. The sizes of the sporangia were measured under a dissecting microscope. The colour code numbers refer to Maerz \& Paul (1950). For small sporangia it was difficult to find a corresponding colour square even under a hand lens. For microscopical characters, such as spore colour, comparisons with the colour chart were not made because of the different lighting for the specimen and colour chart. Spore sizes are given here as means of ten measurements accurate to within $0.5 \mu \mathrm{m}$.

Species were identified from the following books: Lister (1926), Martin \& Alexopoulos (1969), Nannenga-Bremekamp (1974).

\section{List of species}

Of the 19 species of slime moulds detected, eight were new to Finland. The species are described here in systematical order according to NannengaBremekamp (1974). The number of specimens in the three habitats is given under the following symbols: $\mathrm{L}=$ Luukkaa, the virgin forest, $\mathrm{S}=$ Seutula, the managed forest, $\mathrm{B}=$ the Botanical Garden of the University of Helsinki. Each variable is described with three numbers (e.g. 3-18-49 days), indicating the smallest, mean, and greatest values. Total distribution range is according to Martin \& Alexopoulos (1969) and the Finnish range according to Härkönen (1974).

\section{Echinostelium minutum de Bary}

85 specimens: L 69 / S $16 /$ B -. 60 on conifers, 25 on deciduous trees. 56 specimens (66\% of all) on Pinus sylvestris. $\mathrm{pH}$ of substrate $2.5-5$. Incubation time 3-1849 days. Probably cosmopolitan. New to Finland.

Sporangia stalked, scattered or gregarious, 220$421-600 \mu \mathrm{m}$ high. Head globose $35-49-60 \mu \mathrm{m}$ diam. Peridium represented only by a collar round the stem. Stalk hair-like, white or black or upper part white and lower part black, somewhat shining, 4-8 times as long as sporangium, in transmitted light yellow and filled with granular material at least below; thickness below collar $1-2.6-8 \mu \mathrm{m}$ and at base $8-13.8-24 \mu \mathrm{m}$. Columella small, ending in a scanty, dichotomously branched, seldom anastomosing capillitium with pointed tips (see Figs. 1-2). Spores hyaline in transmitted light, smooth, $5.5-6.5-8 \mu \mathrm{m}$ in diam.

Two colour forms, white and pinkish, are recognized by Alexopoulos (1960). In the present material the developing sporangia of 18 specimens were deep pink, the others being white or pale pinkish. About 1 year later all the specimens looked white or nearly so (2 A 1, 2 B 1) under a dissecting microscope with a mercury lamp which is said to resemble daylight.

\section{Echinostelium cribrarioides Alex.}

Three specimens, all from L. All on Betula at $\mathrm{pH} 5$. Incubation time 10, 22 and 24 days. Repoted from Greece and Dominica (Martin \& Alexopoulos 1969), the Netherlands (Nannenga-Bremekamp 1974), and France (Mitchell \& Nannenga-Bremekamp 1976). New to Finland.

Sporangia $264-317-350 \mu \mathrm{m}$ tall, head white, $48-58-72 \mu \mathrm{m}$ in diam., with no peridium except a basal collar. Stalk about four times height of sporangium, white or with white upper and black lower part, yellow in transmitted light and filled 

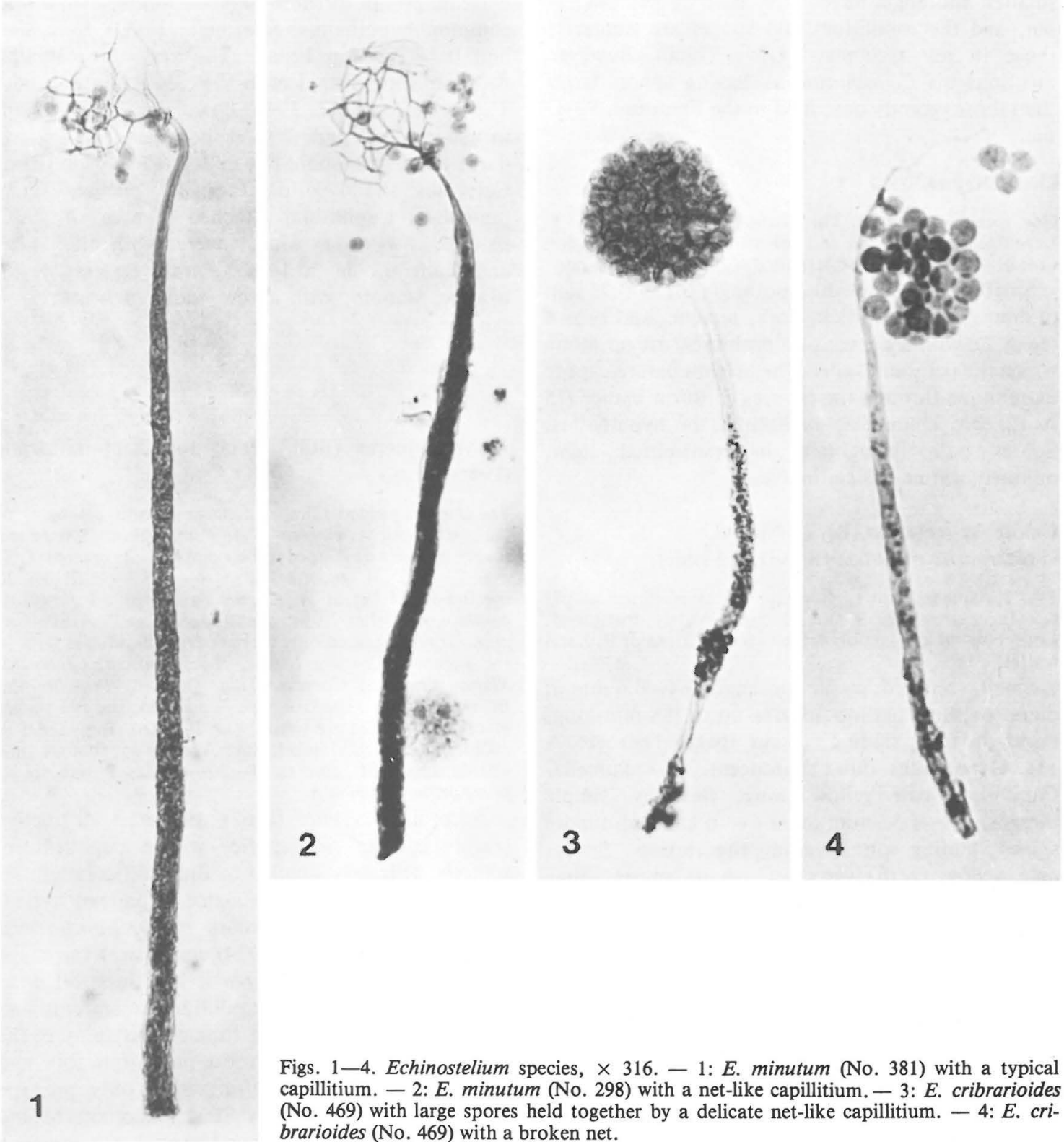

Figs. 1-4. Echinostelium species, $\times 316 .-1:$ E. minutum (No. 381 ) with a typical capillitium. - 2: E. minutum (No. 298) with a net-like capillitium. - 3: E. cribrarioides (No. 469) with large spores held together by a delicate net-like capillitium. $-4: E$. cribrarioides (No. 469) with a broken net.

with granular material, under collar $2-2.2-5 \mu \mathrm{m}$ in diam., and at base $11-12-13 \mu \mathrm{m}$. Columella short, dividing into capillitial net with large meshes, which tend to break when one tries to wash out the spores. (The spores stay within the sporangium on the slide, whearas in $E$. minutum they escape spontaneously. See Figs. 3-4.) Spores hyaline, with distinctly plate-like areas, $10-10.1-10.5 \mu \mathrm{m}$ in diam.
My specimens do not exactly correspond to the original description of the species (Alexopoulos 1961). The sporangium has a smaller head, and the capillitium does not show such a complete globose net. But the spores are typical and clearly larger than the largest spores $(8 \mu \mathrm{m})$ of my specimens of $E$. minutum. The specimen correspond better to the description and drawings of Nannenga-Bremekamp (1974). In a duplicate of her specimen 9487, the 
smallest sporangia have a diameter of less than 50 $\mu \mathrm{m}$, and the capillitium and spores are similar to those in my specimens. Olive (1960), however, mentions his $E$. minutum as having spores larger than those recently described in the literature, 9-13 $\mu \mathrm{m}$.

\section{Licea minima Fr.}

One specimen from B. On Taxus cuspidata at $\mathrm{pH} 4.5$. Developed, after drying and rewetting in total incubation time of 47 days. Widely distributed. Common in Finland.

Small, scattered, sessile sporangia $0.15-0.25 \mathrm{~mm}$ in diam. Peridium thick, dark, opaque, and brown (16 A 2), with a network of prominent ridges along which the peridium splits. The bright-coloured spore mass shows through the fissures as Burnt umber (15 A 12). No columella, capillitium, or hypothallus. Spores pale ferruginous in transmitted light, minutely warted, $10 \mu \mathrm{m}$ in diam.

\section{Calomyxa metallica (Berk.) Nieuwl. (Margarita metallica (Berk.) A. Lister)}

Two specimens from L. Both on Alnus glutinosa at $\mathrm{pH}$ 4.5. Incubation time 9 and 17 days. Widely distributed. From Finland known only from two collections of P. Karsten $(\mathrm{H})$.

Small, scattered, sessile sporangia $0.4-0.6 \mathrm{~mm}$ in diam. or short plasmodiocarps up to $0.8 \mathrm{~mm}$ long. Peridium thin, shining, colour Biskra Date (16 A 12). Hypothallus thin, translucent. No columella. Capillitium pale yellow, long, flexuous, simple threads, $0.8-1.5 \mu \mathrm{m}$ in diam., with band of minute spines winding spirally along the threads. Spores pale yellow, with warts and sharp spines, 10$10.5-11 \mu \mathrm{m}$ in diam.

\section{Perichaena chrysosperma (Currey) A. Lister}

Two specimens from L. Both on Populus tremula covered with mosses at pH 5.5 in 13 and 36 days. Cosmopolitan. New to Finland.

Sporangia $0.3-0.6 \mathrm{~mm}$ in diam., sessile or having extremely short, thick, black stalks or short plasmodiocarps up to $1.5 \mathrm{~mm}$ long. Outer peridium thick, shining; colour Chestnut (7 E 10); inner layer thin, translucent. Dehiscence irregular. No hypothallus. Capillitium threads yellow, 2-5 $\mu \mathrm{m}$ thick, some with short papillae, some with spines up to $2 \mu \mathrm{m}$ long, and most with both. Spores yellow, minutely warted, $10-10.5 \mu \mathrm{m}$ in diam.

\section{Arcyria incarnata (Pers.) Pers.}

Two specimens from L. Both on Alnus glutinosa at $\mathrm{pH}$ 4.5. One developed in 17 days, the other, after drying and rewetting, in 35 days. Cosmopolitan. Common in Finland.
Dense groups of short-stalked sporangia on a thin common hypothallus. Sporangia $1-1.8 \mathrm{~mm}$ high and $0.3-1.2 \mathrm{~mm}$ broad. The very thin, shining peridium soon evanesces as the capillitium expands. The red-brown (7 J 9) coalescing plasmodium turned into pale pink (2 C 9) sporangia. Stalk short, dark, filled with spore-like cells $8-16 \mu \mathrm{m}$ in diam. Calyculus shallow, longitudinally plicate, finely punctuate. Capillitium attached to apex of stalk, pale pink, 3-4 $\mu \mathrm{m}$ wide, covered with blunt pegs and halfrings in a loose spiral. Spores nearly hyaline, smooth, with a few scattered warts, 7-8 $\mu \mathrm{m}$.

Arcyria cinerea (Bull.) Pers. and A. pomiformis (Leers) Rost.

The samples yielded 128 specimens apparently belonging to the species pair $A$. cinerea $-A$. pomiformis; 15 were too scanty or badly developed to be examined. $A$. cinerea: $\mathrm{L} 37$ / S 7 / B 5; A. pomiformis: L - / S - / B 59. 36 specimens (74 \%) of $A$. cinerea developed on Juniperus communis. Other substrates: Malus and Alnus. $A$. pomiformis appeared only on bark from deciduous trees in the Botanical Garden: Ulmus, Acer, Syringa, Crataegus, Malus, Fraxinus, Corylus, Tilia, Quercus, Populus and Betula. Although the tree species differed, the $\mathrm{pH}$ ranges of the two species are similar (see Fig. 16). Both seem to avoid the most acid substrates. Average incubation time was longer in $A$. cinerea $(3-20-41$ days) than in $A$. pomiformis (3-9-40).

According to Farr (1962), the main distinctive feature of the two species is the cup texture: smooth, delicately stippled or finely reticulate in $A$. cinerea, and marked with coarse, prominent reticulations, papillae, or blotches in $A$. pomiformis. Nannenga-Bremekamp (1974) emphasizes the shape of capillitium. In $A$. cinerea it has three different parts. At its base the capillitium is smooth and thick, becoming somewhat thinner and spiny in the middle, and in the uppermost parts it is thin and bears long spines. A. pomiformis has only one type of capillitium. A study by SEM (Schonknecht and Small 1972) revealed that: "Although the capillitia of $A$. pomiformis are much larger than those of $A$. cinerea, they are morphologically similar. The capillitia of both species are ornamented with blunt spines.» Using SEM Robrecht (1973) found two capillitial types in $A$. cinerea, one finely built with an av. diam. of $2.2 \mu \mathrm{m}$ and the other massively built with an av. diam. of $3.7 \mu \mathrm{m}$.

In the present study 49 specimens with a smooth or almost smooth cup and at least two types of capillitium were referred to $A$. cinerea, another 59 
with a cup with prominent reticulations and only one type of capillitium being referred to $A$. pomiformis (see following list). Five specimens were exceptional in one way or another.

$\begin{array}{ll}\text { A. } \text { cinerea } & \text { A. pomiformis } \\ 49 \text { specimens } & 59 \text { specimens }\end{array}$

Total height $\quad 0.4-1.6-2.8 \mathrm{~mm} 0.3-0.9-1.5 \mathrm{~mm}$

Diameter $\quad 0.2-0.4-0.7 \mathrm{~mm} 0.1-0.3-0.6 \mathrm{~mm}$

Ratio stalk/total $\quad 0.2-0.4-0.6 \quad 0.1-0.5-0.7$ height

Shape of

sporangium

Colour

ate to cylindri-

cal, sometimes

ovate to globose, with fused stalks

grey, sometimes greenish yellow to with a yellowish bright yellow (light tint (ivory $10 \mathrm{~B} \mathrm{2,} \mathrm{stone} 12 \mathrm{~J} 5$, oyster white $10 \mathrm{~B}$ popcorn $9 \mathrm{~J} 3$ ) 1 , beige $11 \mathrm{C}$ )

Peridium

thin, shining; not persistent though fugacious, mostly some

fragments left

Cup markings

smooth or delica- fragmented tely punctuate reticulations

Hypothallus

Stalk

Capillitium

mostly present

same colour or

lighter or darker than sporangium filled with sporelike cells 8-44 $\mu \mathrm{m}$ in diam

\section{dense, not} expanding the base smooth or nearly smooth $2-8 \mu \mathrm{m}$, the apical part 1.5$3.5 \mu \mathrm{m}$ with long sharp spines

mostly absent

same colour or lighter or darker than sporangium filled with sporelike cells $8-40 \mu \mathrm{m}$

more robust, less dense, expanding, only one type with cogs, short spines or half rings, $2.5-8 \mu \mathrm{m}$

Habitat:

Specimens on $\quad 36$

conifers

Specimens on

deciduous trees

Specimens in:

Botanical Garden

Virgin forest

37

Managed forest
Robrecht (1974) does not agree with Farr's opinion that the stalk in the two species in similar and not useful for distinguishing the species. He draws attention to the spore-like cells in the stalk: In A. pomiformis the stalk is filled with spore-like cells, that are large (av. diam. 25 um up to $38 \mu \mathrm{m}$ ) and somewhat polygonal while those of $A$. cinerea are smaller $(15-21 \mu \mathrm{m})$ and more rounded. In some specimens of the present material the spore-like cells were difficult to distinguish and could not be measured. In general, the spore-like cells also varied greatly in size and so only the largest and the smallest were measured. In both species the size of the spore-like cells gradually diminishes towards the apex. The smallest cells are often about the size of true spores and can be distinguished from them only by the absence of scattered warts. From. Fig. 5 it is evident that although on averange the cells in $A$. pomiformis are larger, the overlap is great.

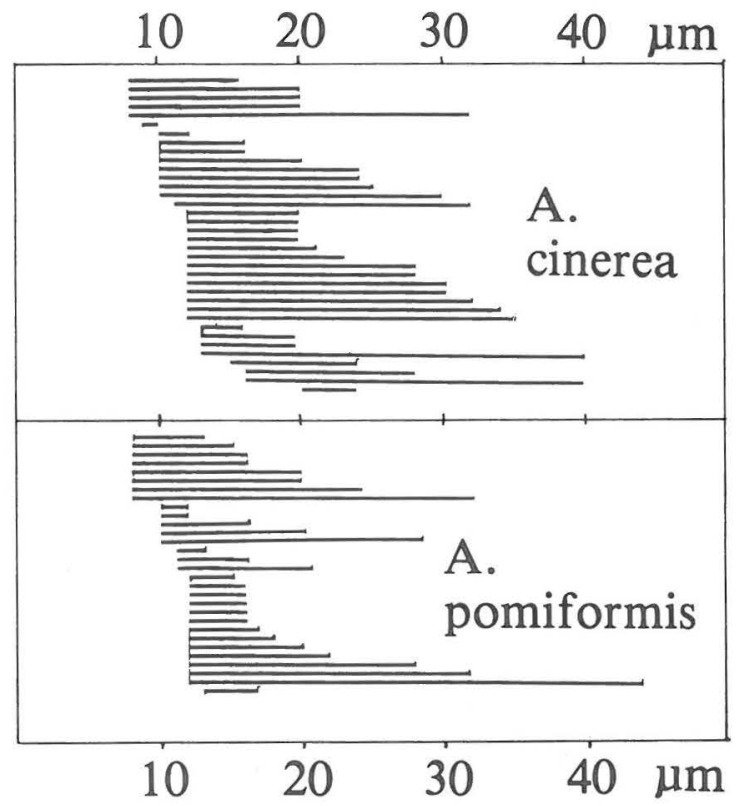

Fig. 5. The size ranges of the spore-like cells in the stalks of Arcyria cinerea and A. pomiformis.

In this material $A$. cinerea was always grey, and A. pomiformis always showed some tints of yellow, never grey. In mature specimens $A$. pomiformis always had a somewhat expanded capillitium and there was never any peridium left. $A$. cinerea mostly had a thin peridium or at least fragments of it left 
and the spores were so firmly attached within the sporangium that it was difficult to blow them away. The spores of the two species are similar; even the slight size difference that Farr (1962) reports, $A$. cinerea 6-7 $\mu \mathrm{m}$, A. pomiformis (6-) 7-8 (-9) $\mu \mathrm{m}$, is hardly a reality (see Fig. 6).

Three specimens have an almost smooth cup, but only one type of capillitium. All of them are greyish, and the capillitium is not expanded. So they are nearest to $A$. cinerea and, as Farr (1962) writes, the cup markings seem to be the most constant character for distinguishing the two species.

Two specimens with very small sporangia have no cup. Otherwise they are typical $A$. pomiformis.
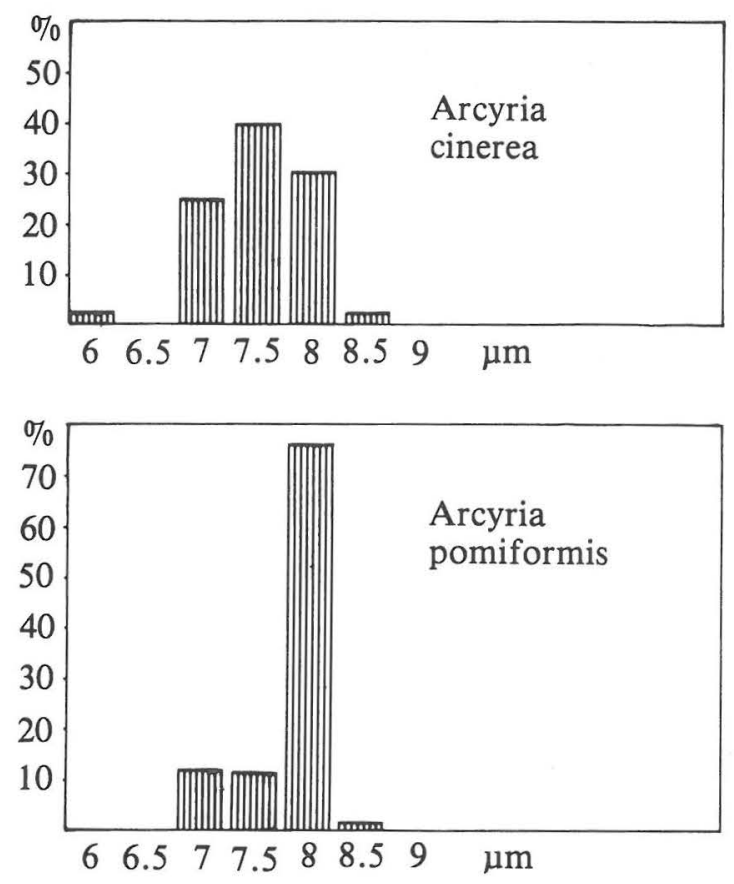

Fig. 6. The spore dimensions of Arcyria cinerea and $A$. pomiformis.

Trichia botrytis (J. F. Gmel.) Pers.

One specimen from L. On Betula at pH 5 after rewetting, appearing after 40 days' incubation. Widely distributed, collected in different parts of Finland, too.

Sporangia stalked, solitary or in twos on one stalk, pyriform, $0.4-0.5 \mathrm{~mm}$ in diam., total height $0.8-1 \mathrm{~mm}$. Outer peridium thick, mottled: sepia $(8$ A 10) plates on a buff (11 K 7) background. Inner peridium membranous. Stalk opaque, furrowed, nearly black, filled with amorphous material. Hypothallus thin, dark brown. Elaters consist of smooth spirals, yellow, $4 \mu \mathrm{m}$ in middle and gradually tapering to long tips. Spores not swelling properly, pale yellow and minutely warted, about 11 $\mu \mathrm{m}$ in diam.

\section{Stemonitis pallida Wingate}

One specimen from L. On Junipers communis on mosses at $\mathrm{pH} 4.5$ in 32 days. According to Martin \& Alexopoulos (1969), distributed in Europe, the Malay Peninsula, Japan, and the Eastern United States to Iowa. Found also in Africa, Angola (Almeida 1974) and the Galapagos Islands (Eliasson 1971). New to Finland.

The dark hypothallus bore 13 sporangia in a dense cluster. Total height about $3 \mathrm{~mm}$, stalk $1 \mathrm{~mm}$; thickness of single sporangium about $0.3 \mathrm{~mm}$. Stalk black. Sporangia sepia (8 A 10). The dark columella becomes thinner and lighter towards the apex. Surface net pale brown; meshes angular, spinulose, about $4-30 \mu \mathrm{m}$ in diam, absent from top of sporangium. Spores pale brown in transmitted light, minutely warted, $7-8 \mu \mathrm{m}$ in diam.

\section{Comatricha elegans (Racib.) G. Lister}

One specimen with a single sporangium from L. On Alnus glutinosa, $\mathrm{pH} 5$, after 37 days. Widespread. New to Finland, but known from Sweden (Santesson 1964).

Sporangium globose, stipitate, $0.2 \mathrm{~mm}$ in diam. Total height $1 \mathrm{~mm}$. Stalk black, $68 \mu \mathrm{m}$ thick at base, $8 \mu \mathrm{m}$ at tip. No hypothallus. Columella short, dividing into four stout main branches, which then divide again into a slender, flexuous, anastomosing capillitium. Spores pale brown, evenly and minutely warted, $8 \mu \mathrm{m}$ in diam.

\section{Comatricha nigra (Pers.) Schroet.}

79 specimens: L 25 / S 3 / B 51. Seems to prefer coniferous trees (79 \% of specimens). 26 specimens on Larix spp., 23 on Picea abies. Other substrates: Pinus sp., Pinus sylvestris, Pseudotsuga, Thuja, Picea, Alnus, Populus, Sorbus, Crataegus, Ulmus, Betula, Quercus. On rather acid media, $\mathrm{pH} \mathrm{2-5.} \mathrm{Development} \mathrm{took} \mathrm{7-30-46} \mathrm{days.}$ Mostly (in $68 \%$ of cases) the medium had to be dried and rewetted before $C$. nigra appeared. Cosmopolitan and also common in Finland.

Sporangia scattered or in small groups. Total height $0.7-2-3.5 \mathrm{~mm}$. (Possibly fructifications develop smaller in moist chambers than in nature; Martin \& Alexopoulos (1969) give the size limits as 2-8 mm.) Head of sporangium dark brown (8 $\mathrm{E}$ 10), $0.25-0.4-0.8 \mathrm{~mm}$ in diam., mostly globose, sometimes ovate. Peridium evanescent. Stalk black, thin; width $40-85-150 \mu \mathrm{m}$ at base, at apex $8-15.5-16 \mu \mathrm{m}$. Ratio of head to total height $0.1-$ 0.2-0.4. Hypothallus small, thin, transparent, brownish or lacking, sometimes continuing round the stalk as a hyaline sheath. Columella reaches from $1 / 4$ to top within sporangium, mostly $2 / 3$. 
Capillitium dark, flexuose, branching and anastomosing, forming dense net and especially at top of sporangium having many, sometimes swollen, free ends. Spores dark brown in mass and light violaceous brown by transmitted light, never dark as stated by Martin \& Alexopoulos (1969), faintly warted to nearly smooth. Some, at least, of the spores in every specimen have a paler and smoother area on one side. Diameter 7.5-8.3-10 $\mu \mathrm{m}$, somewhat less than the (8-) 9-10 (-11) $\mu \mathrm{m}$ given by Martin \& Alexopoulos (1969), but fitting well with the data on Dutch material, 7.5-9 $\mu \mathrm{m}$ (Nannenga-Bremekamp 1974). Plasmodium colourless, but turning white when beginning to coalesce. Then the stalks inside the white mass turn black. As the black stalks grow, the plasmodium moves up and forms white heads of the young sporangia. These then turn pink, red, dark red, and finally black (cf. Goodwin 1961). While maturing, the head dries and turns brown (see Figs. 7-11).

\section{Enerthenema papillatum (Pers.) Rost.}

29 specimens: L 27 / S 1 / B 1. Seems to prefer coniferous bark. 25 specimens ( $85 \%$ of all) on conifers, 16 being on Picea abies. $\mathrm{pH}$ rather low, 3-5. Incubation time 3-2641 days. Widely distributed; common in Finland.

Sporangia scattered or in small groups. Total height $0.6-0.8-1 \mathrm{~mm}$. Head $0.3-0.6-1 \mathrm{~mm}$ in diam., dark brown (like 16 A 6-12 but darker). Peridium evanescent except for some silvery-grey flakes on some sporangia and basal ring around the stalk in most of them. Stalk stout, shining black, opaque, averaging somewhat under $1 / 3$ of total height or absent; length never as great as diameter of sporangium (Martin \& Alexopoulos 1969; about equal to the sporangium). Stalk then narrows to a columella, which reaches top of sporangium. Columella terminating in a shining black plate 28-128$320 \mu \mathrm{m}$ in diam. Capillitial threads black, flexuous, spreading downwards from apical disk. Near the tips they divide dichotomously once or twice and have some uneven warts. Hypothallus inconspicuous. Spores greyish brown in transmitted light, minutely warted, $9.5-11-12 \mu \mathrm{m}$ in diam. Plasmodium in coalescence white. Developing sporangia turn successively pink, dark red and black.

Figs. 7-11. The development of Comatricha nigra (No. 248), $\times$ 11. - 7: white, 8: pink, 9: red, 10: black, 11: partially mature, brown sporangia. Between the last two photos there are 12 hours, between the others two hours.
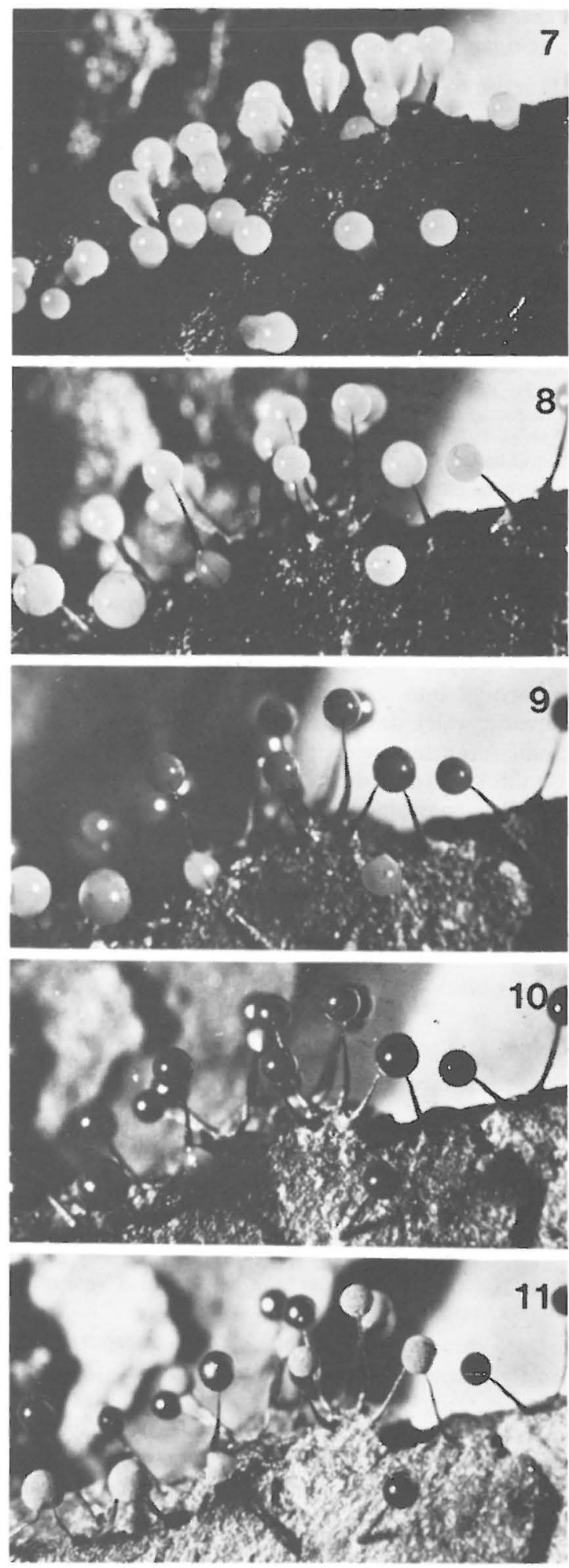
Paradiacheopsis fimbriata (G. Lister \& Cran) Hertel (Comatricha fimbriata G. Lister \& Cran)

217 specimens: L - / S 33 / B 184. On 27 tree species, 65 specimens on coniferous bark, 152 on deciduous bark. Commonest on Acer and Ulmus. Most abundant on bark that was green with Bacidia chlorococca (cf. Ing 1976: »Usually associated with the alga Pleurococcus. ») The $\mathrm{pH}$ range of the substrates was very wide, from $\mathrm{pH} 2$ to $9 . P$. fimbriata is the most abundant Myxomycete species in the Botanical Garden. In the virgin forest none developed. All the Paradiacheopsis there proved to be $P$. solitaria. The time needed for development was mostly short, 3-10-43 days. Distribution: Great Britain, the Netherlands (common: Nannenga-Bremekamp 1974), Belgium, Greece and several states in the U.S.A. (Martin \& Alexopoulos 1969), France (Mitchell \& Nannenga-Bremekamp 1976); also found in Sweden (Santesson 1964) and Czechoslovakia (Svrček 1972). Possibly common in Finland, although not found before, because of its small size.

Sporangia stalked, dark brown, nearly black, scattered, globose. Total height $0.3-0.7-1.1 \mathrm{~mm}$. No peridium, and spores flow away easily, leaving naked capillitium. Stalk black, fibrillose, expecially below, where the colour also turns brown, much thicker, $20-73-280 \mu \mathrm{m}$ at base than on top, 2-8-24 $\mu \mathrm{m}$. Hypothallus small. Columella short, branching into very delicate, colourless capillitial threads, which darken and thicken towards the tips. Some branches with prominently expanded tips. Capillitial threads dichotomously forked, but mostly without anastomoses (see Fig. 12-13). Spores purplish grey-brown, minutely spinulose, paler and smoother on one side, some of them slightly oval, $10-12-14 \mu \mathrm{m}$ in diam. Plasmodium colourless, turning white when beginning to coalesce. Stalk then turns black and head pink, coral red, dark red and finally black.

\section{Paradiacheopsis solitaria (Nann.-Brem.) Nann.- Brem.}

(Comatricha solitaria Nann.-Brem.)

10 specimen, all from L. 6 specimens on Alnus glutinosa, 3 on Juniperus communis, one on Picea abies. Substrate $\mathrm{pH}$ $3.5-5$. Incubation time $4-9-17$ days. So far reported only from the Netherlands (Nannenga-Bremekamp 1962), Great Britain (Ing 1967) and France (Mitchell \& NannengaBremekamp 1976). New to Finland.

Dark brown, almost black, stalked sporangia, mostly standing solitarily, but some of them in colonies, the largest having nearly a hundred sporangia. Total height $0.7-0.9-1.2 \mathrm{~mm}$. Sporangia globose, $0.25-0.4-0.6 \mathrm{~mm}$ in diam. No peridium. No hypothallus. Stalk black, fibrous at base, at apex $12-39-72 \mu \mathrm{m}$, at base $80-142-240 \mu \mathrm{m}$ in diam. Columella ends about halfway in sporangium.
Capillitium black and stout throughout, branching dicotomously, but usually without anastomoses. Tips not expanded. Spores in transmitted light greyish brown, minutely and evenly warted, $12-13.5-16 \mu \mathrm{m}$ in diam. Nannenga-Bremekamp (1962), in the description of the species, gives the spore size as (13-) 14-16 (-20) $\mu \mathrm{m}$. Maybe the range should be widened a little, because even on the slide I received from her (No. 9287) there are spores $12 \mu \mathrm{m}$ in diameter.

According to Martin \& Alexopoulos (1969), $P$. solitaria may well be no more than an extreme variant of $P$. fimbriata. However, the capillitium of $P$. solitaria, which is rigid throughout, makes the two species clearly distinguishable (See Figs. 1214).

\section{Physarum viride (Bull.) Pers.}

Three specimens from L. All on Betula at pH 5 and only after drying and rewetting. Incubation time $31-33-35$ days. Cosmopolitan. Widely distributed in Finland.

Scattered, stalked sporangia $0.9-1.1 \mathrm{~mm}$ tall. Sporangia globose to lenticular, some of them nodding, $0.25-0.4 \mathrm{~mm}$ broad, $0.2-0.3 \mathrm{~mm}$ high. Peridium fragile, covered with yellow ( 9 K 2) lime granules. Stalk furrowed, bright orange at apex and dark brown below, containing no lime; upper half transparent in transmitted light, lower half thicker and filled with refuse matter. No columella. Hypothallus a small dark plate. Capillitium hyaline, with fusiform orange or greenish yellow lime nodes. Spores pale lilac brown in transmitted light, finely warted, with some bigger warts in denser groups, $8-8.5-9 \mu \mathrm{m}$ in diam.

\section{Physarum oblatum Macbr.}

(Physarum maydis (Morgan) Torrend)

One specimen from L. On Juniperus communis at $\mathrm{pH} 5$ in 21 days. According to Martin \& Alexopoulos (1969) cosmopolitan. Found in Finland only once before (Satakunta: Kankaanpää, 6. II. 1935 Matti Laurila, H) and not reported from the other $\mathrm{N}$ European countries or even from Netherlands.

11 stalked sporangia in two small groups. Total height $0.9-1.1 \mathrm{~mm}$. Sporangia globose $0.3-0.4$ $\mathrm{mm}$ in diameter. Peridium membranous, roughened with golden yellow (9 L 6) lime granules; base darker, having same tint as stalk. Stalk red-brown, transparent, furrowed, having no lime or refuse matter. No columella. Hypothallus inconspicuous. Capillitium hyaline having many large, irregular lime nodules of same colour as lime on peridium. Spores purple brown in transmitted light, finely and evenly warted, 1 i $\mu \mathrm{m}$. 


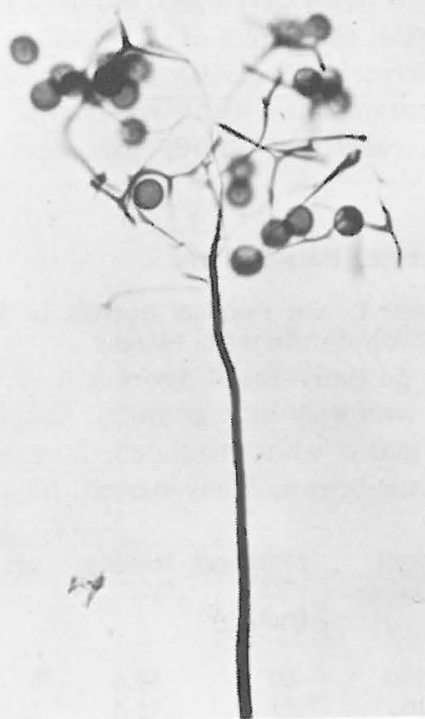

12

13
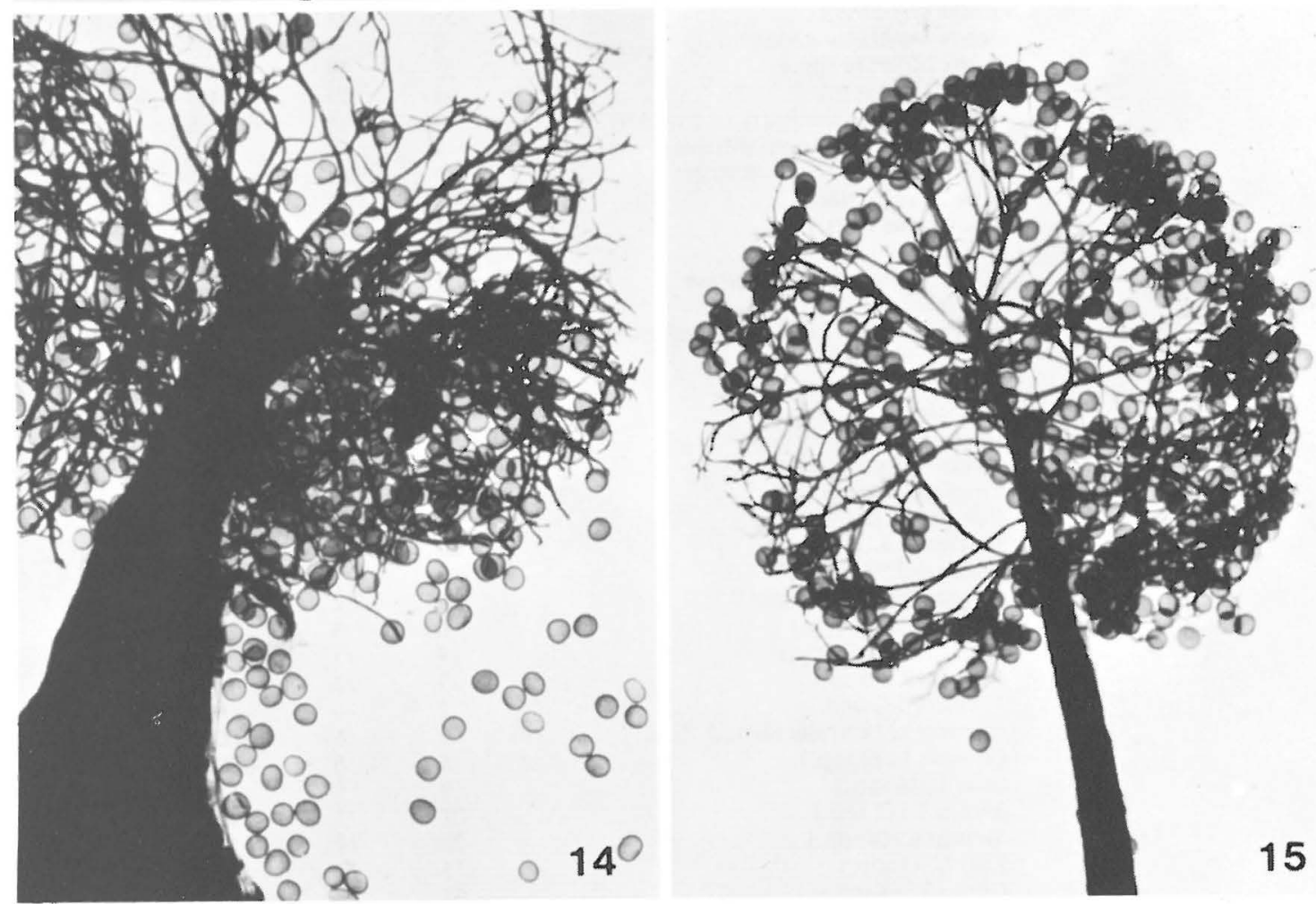

Figs. 12-15. Paradiacheopsis species, $\times 162 .-12: P$. fimbriata (No. 649), a typical sporangium. $-13:$. fimbriata (No. 577) with an abundant capillitium. - 14: $P$. solitaria (No. 534) - 15: $P$. solitaria (No. 665). 
Physarum pusillum (Berk. \& Curt.) G. Lister

One specimen from L. On bark of Sorbus aucuparia at $\mathrm{pH}$ 5.5 only after drying and rewetting, in 41 days. Cosmopolitan. New to Finland. Bjфrnekaer \& Klinge (1963) report it from Denmark.

Six scattered, stalked sporangia $0.5-1 \mathrm{~mm}$ high. Sporangia slightly flattened and umbilicate below, $0.25-0.6 \mathrm{~mm}$ in diam. Peridium thin, brownish grey (8 C 9, $8 \mathrm{E} \mathrm{9)}$, base thicker and more reddish brown. Some sporangia totally without, some with sparse white lime granules. Stalk cylindrical, furrowed, dark brown, dark yellowish red in transmitted light, having no lime or refuse matter. Stalk merges into dark basal part of sporangium. Hypothallus disk-shaped, brown, transluçent. No columella. Capillitium a network of hyaline threads with sparse white lime nodes. Spores light lilaceous brown, mostly damaged, but the well-developed ones minutely warted with some larger warts in denser groups, $10 \mu \mathrm{m}$.

The specimen is badly developed, but nevertheless, shows the essential characters of $P$. pusillum given by Nannenga-Bremekamp (1974): stalk translucent, red-brown, sporangium with red-brown base, capillitium not radiating, spores pale and finely warted.

\section{Physarum cinereum (Batsch) Pers.}

One specimen from L. On Populus tremula in 5 days. Cosmopolitan. Widely distributed in Finland.

Four sessile, partially fused sporangia, $0.4 \mathrm{~mm}$ broad, covered with grey lime granules. Capillitium hyaline, with many white rounded lime nodes. Spores light purple-brown, finely warted, $10 \mu \mathrm{m}$.
Tree species

Juniperus communis L. Picea abies (L.) Karsten Pinus sylvestris L.

Abies nephrolepis Maxim.

Larix Miller (6 spp.)

Pinus L. (4 spp.)

Picea engelmannii Parry ex Engelm.

Pseudotsuga menziesii (Mirbel) Franco

Taxus cuspidata Sieb. \& Zucc.

Thuja occidentalis L.

Coniferous trees

Alnus glutinosa (L.) Gaertner

Alnus incana (L.) Moench

Betula pendula Roth. + B. pubescens Ehrh.

Populus tremula L.

Salix caprea L.

Aesculus neglecta Lindl.

Acer L. (5 spp.)

Alnus rubra Bongard

Carpinus betulus L.

Corylus L. (2 spp.)

Crataegus L. (4 spp.)

Fraxinus L. (3 spp.)

Hippophae rhamnoides $\mathrm{L}$.

Junglans L. (2 spp.)

Malus Miller (2 spp.)

Populus L. (6 spp.)

Prunus L. (2 spp.)

Pterocarya rhoifolia Sieb. \& Zucc.

Quercus L. (2 spp.)

Salix L. (4 spp.)

Sorbus L. (2 spp.)

Syringa L. (4 spp.)

Tilia L. (3 spp.)

Ulmus L. (3 spp.)

Vitis labrusca L.

Deciduous trees

Table 1. The tree species used for the moist chambers. Total

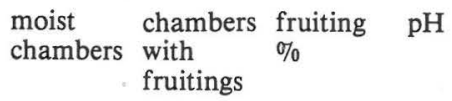

\begin{tabular}{|c|c|c|c|}
\hline 110 & 60 & 54.6 & $4-5.5$ \\
\hline 163 & 51 & 31.3 & $2-4$ \\
\hline 155 & 93 & 60 & $2.5-5$ \\
\hline 2 & - & 0 & \\
\hline 65 & 29 & 44.6 & $2-4.5$ \\
\hline 31 & 13 & 41.9 & $2-4$ \\
\hline 13 & 4 & 30.8 & $3-4.5$ \\
\hline 7 & 5 & 71.4 & $2.5-4.5$ \\
\hline 15 & 13 & 86.7 & $3-5$ \\
\hline 20 & 10 & 50 & $2.5-5$ \\
\hline 581 & 278 & 47.9 & $2-5.5$ \\
\hline 71 & 44 & 62 & $3-5$ \\
\hline 39 & 4 & 10.3 & $5-5.5$ \\
\hline 166 & 37 & 22.3 & $2.5-5.5$ \\
\hline 33 & 6 & 18.2 & $4.5-5.5$ \\
\hline 27 & - & 0 & $4-5.5$ \\
\hline 1 & 1 & 100 & \\
\hline 49 & 39 & 79.6 & $3.5-7.5$ \\
\hline 1 & - & 0 & \\
\hline 4 & 3 & 75 & $4.5-5$ \\
\hline 4 & 3 & 75 & \\
\hline 20 & 11 & 55 & $3-5$ \\
\hline 15 & 13 & 86.7 & $3.5-5$ \\
\hline 2 & 2 & 100 & \\
\hline 6 & 5 & 83.3 & $4-5$ \\
\hline 19 & 15 & 79 & $3-5$ \\
\hline 29 & 22 & 75.9 & $3.5-5.5$ \\
\hline 2 & - & 0 & \\
\hline 5 & 5 & 100 & $3-4$ \\
\hline 6 & 6 & 100 & $2.5-3.5$ \\
\hline 9 & 5 & 55.6 & $4.5-5$ \\
\hline 22 & 3 & 13.6 & $4-5.5$ \\
\hline 22 & 12 & 54.5 & $4-5$ \\
\hline 13 & 12 & 92.3 & $3.5-5$ \\
\hline 61 & 51 & 83.6 & $3-9$ \\
\hline 2 & - & 0 & \\
\hline 628 & 299 & 47.6 & $2.5-9$ \\
\hline 1209 & 577 & 47.7 & $2-9$ \\
\hline
\end{tabular}




\section{IIII. Ecology}

1. Different tree species as habitats for Myxomycetes

Table 1 lists the sources of the material for the moist chamber cultures according to tree species with the respective amplitudes of $\mathrm{pH}$ measured. The $\mathrm{pH}$ values are mostly somewhat below the averages given by Barkman (1958), but the order of the different tree species is about the same.

$47.7 \%$ of the moist chambers yielded Myxomycete fructifications. Alexopoulos (1953) reported a yield of $66 / 271=24.4 \%$, whearas Peterson obtained up to ca. $60 \%$ (Alexopoulos 1963).

There seemed to be no major differences between deciduous and coniferous tree bark as habitats for Myxomycetes. Of those trees for which over 20 bark cultures were set up, the most favourable (productivity over $50 \%$ ) were: Ulmus, Acer, Populus, Alnus glutinosa, Pinus sylvestris, Syringa, Crataegus, Juniperus communis and Thuja, Least productive (slime moulds appearing in less than $25 \%$ ) were Salix caprea, Alnus incana, Sorbus and Populus tremula. The low productivity of Salix caprea, Betula and Alnus incana may be caused by the smoothness of their bark. Salix caprea and Alnus incana also seemed to have very few epiphytic lichens or mosses to make the surface rough enough for trapping Myxomycete spores. As far as $\mathrm{pH}$ is concerned, these unproductive tree barks are not extreme.

Fissured barks with loose texture (e.g. those of elms and junipers) are mentioned as favourable for a number of Myxomycetes, while barks of Junglans and Salix have proved unfavourable (Brooks 1976, Keller \& Brooks 1973). In Finland as elsewhere Ulmus bark was the most productive, even though collected only from cultivated trees. Salix caprea was unproductive. Of native Finnish trees Pinus sylvestris, Alnus glutinosa and Juniperus communis, all with fissured bark, were the most favourable.

Some of the more abundant Myxomycete species developed more often on a certain group of tree species, Comatricha nigra and Enerthenema papillatum on conifers, Arcyria pomiformis on deciduous trees, others, like Echinostelium minutum (on Pinus sylvestris) and Arcyria cinerea (on Juniperus communis), preferring a single tree species. Pirola \& Credaro (1975), in making a synecological arrangement of Myxomycetes found in Italy, claim that Enerthenema papillatum is limited to coniferous forests whilst Comatricha nigra is present in both coniferous and deciduous forests.
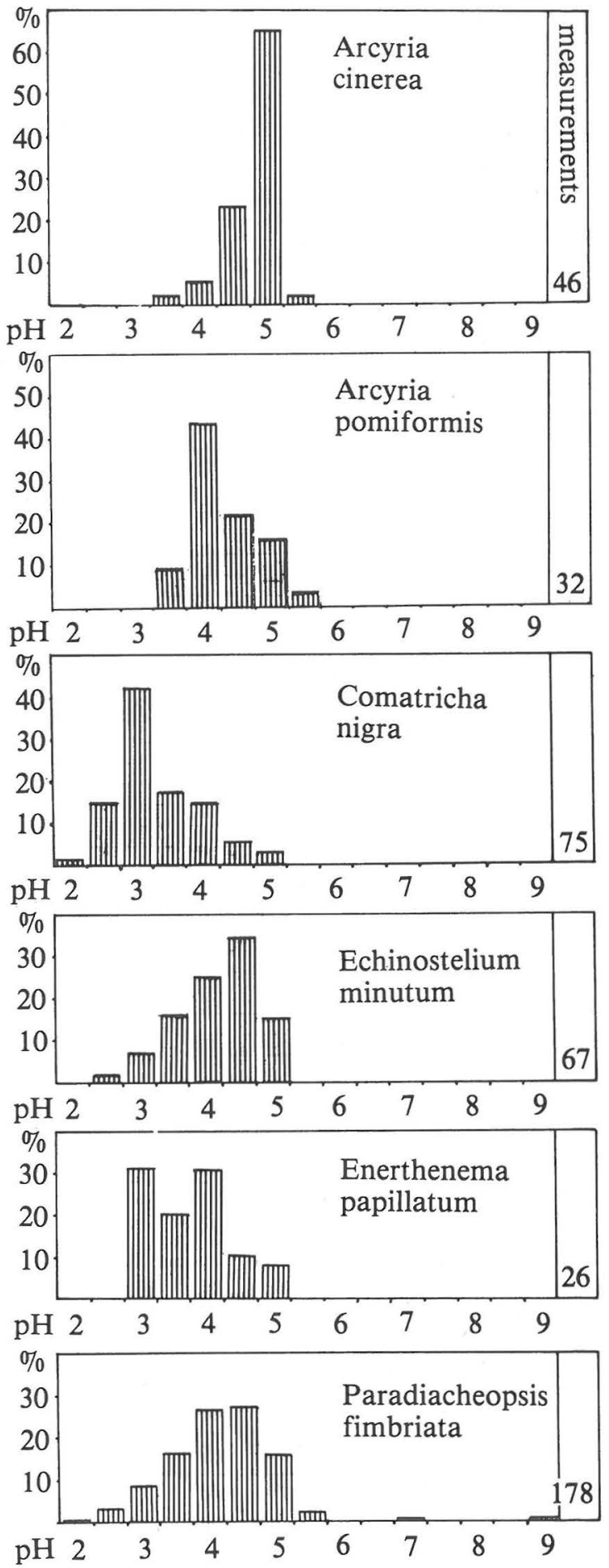

Fig. 16. $\mathrm{pH}$ of the substrates of the six most abundant species of Myxomycetes. 
Table 2. The collecting sites from June to November 1975.

\begin{tabular}{llllllllll} 
& \multicolumn{3}{l}{ Botanical garden } & \multicolumn{3}{c}{ Virgin forest } & \multicolumn{3}{c}{ Managed forest } \\
& $\begin{array}{l}\text { no.of } \\
\text { moist } \\
\text { chambers }\end{array}$ & $\begin{array}{l}\text { no. } \\
\text { slime } \\
\text { moulds }\end{array}$ & $\begin{array}{l}\text { produc- } \\
\text { tivity } \\
\%\end{array}$ & $\begin{array}{l}\text { no. of } \\
\text { moist } \\
\text { chambers }\end{array}$ & $\begin{array}{l}\text { no. of } \\
\text { slime } \\
\text { moulds }\end{array}$ & $\begin{array}{l}\text { produc- } \\
\text { tivity } \\
\text { \% }\end{array}$ & $\begin{array}{l}\text { no. of } \\
\text { moist } \\
\text { chambers }\end{array}$ & $\begin{array}{l}\text { no. of } \\
\text { slime } \\
\text { moulds }\end{array}$ & $\begin{array}{l}\text { produc- } \\
\text { tivity } \\
\%\end{array}$ \\
June & 50 & 32 & 64 & 50 & 33 & 66 & 50 & 14 & 28 \\
July & 50 & 42 & 84 & 50 & 29 & 58 & 50 & 19 & 38 \\
August & 50 & 51 & 102 & 50 & 21 & 42 & 50 & 16 & 32 \\
September & 50 & 46 & 92 & 50 & 28 & 56 & 50 & 11 & 22 \\
October & 50 & 43 & 86 & 50 & 32 & 64 & 50 & 11 & 22 \\
November & 50 & 39 & 78 & 50 & 28 & 56 & 50 & 7 & 14 \\
Total & $\mathbf{3 0 0}$ & $\mathbf{2 5 3}$ & $\mathbf{8 4}$ & $\mathbf{3 0 0}$ & $\mathbf{1 7 1}$ & $\mathbf{5 7}$ & $\mathbf{3 0 0}$ & $\mathbf{7 8}$ & $\mathbf{2 6}$
\end{tabular}

\section{2. $\mathrm{pH}$ of the substrate}

The $\mathrm{pH}$ of the substrate was measured in the 3-dayold cultures and again when fructifications began to appear. In cultures that were dried and rewetted, the measurement was repeated again on the third day after the procedure. No noteworthy changes of $\mathrm{pH}$ were recorded during incubation or drying. This seems essential, since a certain stability of $\mathrm{pH}$ is considered important for success of the culture (Mock \& Kowalski 1976).

The $\mathrm{pH}$ of the bark was lower in conifers (2-5.5) than in deciduous trees (2.5-9). Even on Ulmus with the exceptionally high value of $\mathrm{pH} 9$ (presumably caused by some external influence), Myxomycete fructifications were produced. The lowest $\mathrm{pH}$ at which slime moulds were recorded was 2. Thus in regard to $\mathrm{pH}$ the ecological amplitude seems in general to be wide, but the different slime mould species have different optima and amplitudes (see Fig. 16). E.g. Comatricha nigra seems to prefer an acid substrate, differing clearly in this respect from Arcyria cinerea. Emoto (1939) found the reaction of rotting wood inhabited by Myxomycetes to be 4.2-7.8. In laboratory cultures also, slightly acid media have been found favourable for growth of Myxomycetes (Howard 1931, Smart 1937, Collins \& Tang 1973).

\section{The three habitats as producers of Myxomycetes}

From October 1974 to May 1975, 309 moist chamber cultures were set up for bark samples from the Botanical Garden and from the virgin forest. Unexpectedly, Myxomycete fruiting bodies were produced more frequently by samples from the Botanical Garden $(46 \%)$ than by those from the virgin forest $(19.2 \%)$. Inclusion of material from the managed forest and drying and rewetting treat-

ment of the cultures with no Myxomycetes growth did not alter the main picture. The productivity of samples from the Botanical Garden gave the best results during every month except June, and the samples from the managed forest were least productive (Table 2). According to the $t$ test, the difference in yield as Myxomycete fruiting bodies between the virgin forest and the managed forest was highly significant. The reason may have been that the virgin forest is rich in decaying wood on the ground, whereas the managed forest is not. But another possible influence is Alnus glutinosa which, in the virgin forest, is more common than $A$. incana, the opposite being the case in the managed forest.

The Myxomycete flora of the samples from the Botanical Garden consists of six species, that from the managed forest of five species and that from the virgin forest of 16 species. In the Botanical Garden there were many specimens but few species. Of the six species present in the Botanical Garden three were abundant: Paradiachopsis fimbriata (184 specimens), Arcyria pomiformis (59) and Comatricha nigra (51). The thick old trees with fissured barks planted in the last century evidently afford favourable habitats for slime moulds. The differences in the composition of the slime mould flora are evidently partially due to differences in tolerance to air pollution. For instance, the commonest species in the virgin forest, Echinostelium minutum, seems to be absent from the Botanical Garden. Paradiacheopsis fimbriata, again, is common there, the colonies being especially rich in sites where Bacidia chlorococca turns the bark green. Like this lichen species, which is characteristic of the 'lichen desert' in the centre of cities (Ahti \& Vitikainen 1974), Paradiacheopsis fimbriata may be exceptionally toxitolerant species. 


\section{Corticolous species}

Brooks (1967) writes: »Corticolous slime molds belong predominantly to a few genera, in particular Licea, Macbrideola, Echinostelium and Badhamia. If one restricts consideration to only those species collected in situ this is especially true. Fruitings of species of Arcyria, Hemitrichia, and Stemonitis, though common in ground detritus, appear to be infrequent on tree bark.» This fits my results only partially since, in the present material, the abundant species belong to the genera Arcyria, Comatricha, Echinostelium, Enerthenema and Paradiacheopsis. In the virgin forest Lycogala epidendrum (L.) Fries, Fuligo septica (L.) Wiggers, Physarum nutans Pers., Trichia decipiens (Pers.) Macbr., T. favoginea (Batsch) Pers., and $T$. varia (Pers.) Pers. were common on decaying wood, although they never appeared in the moist chamber cultures.

\section{Seasonal appearence}

Myxomycetous spores are long-lived (Erbisch 1964). In the moist chamber cultures there were no great differences in the numbers of developing Myxomycete fructifications in different months. As a further test, some bark samples were kept in storage, and some unproductive moist chamber cultures were dried out after 4 weeks' incubation. Six months to one year later new moist chamber cultures were set up with these bark samples. Several of them produced Myxomycete fructifications. Myxomycetous spores evidently retain their ability to germinate long enough to suppress any seasonal variation in the cultures and have no internal rhythm to cause germination to occur in any particular season of the year.

\section{Incubation time}

According to Gilbert \& Martin (1933), some species may appear on the second or third day, but most will require 5 or 6 days, and a few will require 2 weeks or more. According to Svrček (1972), some Myxomycetes appear only a few days, others later, after 1 to 2 months. Licea specimens commonly take 2 or more months to mature (Nannenga-Bremekamp in litt.), and fructifications of an undescribed Colloderma continued to appear over a period of about 3 months (Brown \& Celler 1976). In the present cultures 3 days was the shortest time for sporangia to appear, the longest time extending to 28 days before and another 19 days after drying and rewetting. The times needed for development in the six commonest species were as follows:

\section{Echinostelium minutum Arcyria pomiformis \\ A. cinerea \\ Comatricha nigra \\ Enerthenema papillatum \\ Paradiacheopsis fimbriata}

$$
\begin{array}{r}
3-18-47 \\
3-9-40 \\
3-20-41 \\
7-30-46 \\
3-26-41 \\
3-10-43
\end{array}
$$

In the cultures, and no doubt also in nature, the spores germinate unevenly, and some may have needed an interval of drying before germination. The very short incubation times may have been due to the presence of sclerotia, which may need less time to form fructifications. Comatricha nigra and Enerthenema papillatum were the species that most often needed drying and rewetting to develop.

Acknowledgements. - I want to thank Prof. Jaakko Jalas for his advice and constructive criticism in preparing the manuscript, and Dr. Nannenga-Bremekamp for kindly letting me study her large collection of Myxomycetes, and for advising me and reading this manuscript. I also thank Dr. Teuvo Ahti for reading the manuscript and Dr. Tuomo Niemelä for helping me in taking the photographs. 


\section{References}

Ahti, T. \& Vitikainen, O. 1974: Bacidia chlorococca, a common toxitolerant lichen in Finland. - Mem. Soc. Fauna Flora Fennica 49: 95-100.

Alexopoulos, C. J. 1953: Myxomycetes developed in moist chamber culture on bark from living Florida trees with notes on an undescribed species of Comatricha. Quart. J. Florida Acad. Sci. 16: 254-262.

- )-1960: Morphology and laboratory cultivation of Echinostelium minutum. - Am. J. Bot. 47: 37-43.

- » -1961: A new species of Echinostelium from Greece. Am. Midland Nat. 66: 391-394.

- » -1963: The Myxomycetes 2. - Bot. Rev. 29: 1-78.

Almeida, M. G. 1973: Contribuiçăo para o conhecimento dos Myxomycetes de Angola 1. - Bol. Soc. Brotheriana 47: 277-297.

- )-1974: Contribuição para o conhecimento dos Myxomycetes de Angola 2. - Bol. Soc. Brotheriana 48: $187-202$.

Barkman, J. J. 1958: Ecology of cryptogamic epiphytes. -202 pp. Assen.

Bjørnekaer, K. \& Klinge, A. B. 1963: Die dänishen Schleimpilze. Myxomycetes Daniae. - Friesia 7: $149-296$.

Braun, K. L. \& Keller, H. W. 1976: Myxomycetes of Mexico 1. - Mycotaxon 3: 297-317.

Brooks, T. E. 1967: A study of corticolous Myxomycetes. Ph.D. Dissertation, Univ. of Kansas. -244 pp. Lawrence.

Collins, O. R. \& Tang, H. 1973: Physarum polycephalum: $\mathrm{pH}$ and plasmodium formation. - Mycologia 65: $232-236$.

Eliasson, U. 1971: A collection of Myxomycetes from the Gálapagos Islands. - Svensk Bot. Tidskr. 65: 105111 .

- )-1975: Myxomycetes in the Nature Reserve of the Gothenburg Botanical Garden. - Svensk Bot. Tidskr. 69: $105-112$.

Emoto, Y. 1939: Untersuchungen über die Entwicklung der Myxomyceten auf faulenden Hölzern. - Japan. J. Bot. 9: 253-257.

Erbish, F. 1964: Myxomycete spore longevity. - Michigan Botan. 3: 120-121.

Farr, M. L. 1962: Arcyria cinerea and Arcyria pomiformis revised. - Mycologia 54: 516-520.

Gilbert, F. A. 1929: Factors influencing the germination of myxomycetous spores. - Am. J. Bot. 16: 280-286.

Gilbert, H. C. \& Martin, G. W. 1933: Myxomycetes found on bark of living trees. - Univ. Iowa Stud. Nat. Hist. 15: 3-8.

Goodwin, D. C. 1961: Morphogenesis of the sporangium of Comatricha. - Am. J. Bot. 48: 148-154.

Gray, W. D. 1938: The effect of light on the fruiting of Physarum polycephalum. - Am. J. Bot. 25: 511522 .

Gray, W. D. \& Alexopoulos, C. J. 1968: Biology of the Myxomycetes. -288 pp. New York.

Howard, F. L. 1931: Laboratory cultivation of myxomycete plasmodia. - Am. J. Bot. 18: 624-628.

Härkönen, M. 1974: Über die finnischen Schleimpilzen. Karstenia 14: 54-81.
Ing, B. 1967: Notes on Myxomycetes. 2. - Trans. British Mycol. Soc. 50: 555-562.

- >-1976: The natural history of Slapton Ley Nature Reserve 11: Myxomycetes (slime moulds). - Field Stud. 4: $441-456$.

Keller, H. W. \& Brooks, T. E. 1973: Corticolous Myxomycetes 1: two new species of Didymium. - Mycologia 65: 286-294.

Lister, A. 1925: A monograph of the Mycetozoa. 3rd ed., revised by G. Lister. - 296 pp. + 222 pl. London.

Maerz, A. \& Paul, M. 1950: Dictionary of color. 2nd ed. -208 pp. New York.

Martin, G. W. \& Alexopoulos, C. J. 1969: The Myxomycetes. -560 pp. Iowa City.

Micthell, D. W. \& Nannenga-Bremekamp, N. E. 1976: Myxomycetes collected in France and preserved in our private collections. - Proc. Koninkl. Nederl. Akad. Wetenschappen (C) 79: 381-392.

Mock, D. L. \& Kowalski, D. T. 1976: Laboratory cultivation of Licea alexopouli. - Mycologia 68: $370-376$.

Nannenga-Bremekamp, N. E. 1962: Notes on Myxomycetes 6. - Acta Bot. Neerl. 11: 23-34.

- »-1974: De nederlandse myxomyceten. - 440 pp. Zutphen.

Olive, S. O. 1960: Echinostelium minutum. - Mycologia 52: $159-161$.

Pirola, A. \& Credaro, V. 1975: Tentativo di inquadramento sinecologico di mixomiceti italiani. (Abstract: Attempt at synecologic arrangement of some Italian Myxomycetes.) - Not. Fitosoc. 10: 111-130.

Robrecht, $\mathbb{E}$. 1973: Contribution to the knowledge of eight Belgian Arcyria species (Myxomycetes) by scanning electron microscopical study. - Biol. Jaarb. Kon. Nat. Genootschap Dodonaea 41: 183-186.

- 》-1974: The genus Arcyria Wiggers (Myxomycetes) in Belgium. - Bull. Jard. Bot. Nat. Belg. 44: 303-353.

Santesson, R. 1964: Swedish Myxomycetes. - Svensk Bot. Tidskr. 58: 113-124.

Schoknecht, J. D. \& Small, E. B. 1972: Scanning electron microscopy of the acellular slime molds (Mycetozoa $=$ Myxomycetes) and the taxonomic significance of surface morphology of spores and accessory structures. - Trans. Am. Microsc. Soc. 91: 380-410.

Smart, R. F. 1937: Influence of certain external factors on spore germination in the Myxomycetes. - Am. J. Bot. 24: $145-159$.

Stosch, H.-A. von 1965: Wachstums- und Entwicklungsphysiologie der Myxomyceten. - Handb. Pflanzenphysiol. 15: 641-679.

Svrcek, M. 1972: Myxomycety vypèstovane ve vlhkých komůrkách. 1. (Summary: Myxomycetes developed in moist chamber cultures. 1.) - Ceská Mykol. 26: 103113.

Vaarna, V. V. 1934: Helsingin kaupungin puiden ja pensaiden jäkäläkasvisto. (Zusammenfassung: Über die epiphytische Flechtenflora der Stadt Helsinki.) Ann. Bot. Soc. Zool.-Bot. Fennicae Vanamo 6 (6): $1-32$. 